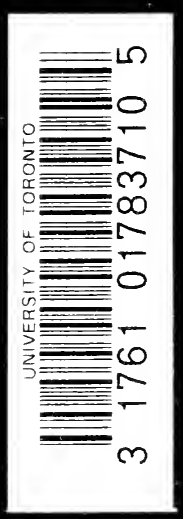



ach $\mathrm{w}^{h \mid+1}$

With the Compliments of

YALE UNIVERSITY LIBRARY

NEW HAVEN, CONN., U. S. A. 
Digitized by the Internet Archive in 2007 with funding from Microsoft Corporation 
THE SOCIAL CRITICISM OF LITERA'TURE 



\section{The Social CRITICISM OF}

\section{LITERATURE}

BY

Ger'TRUde BUCK, Pr.D.

Professor of English in Vassar College

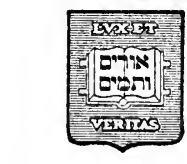

New Haven: Yale University Press

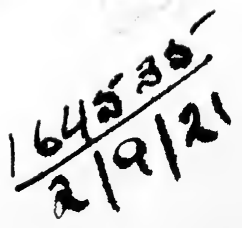

London: Humphrey Milford

Oxford University Press

MDCCCCXVI 
<smiles>C#C[As]=[W]=[W]</smiles> 


\section{PREFACE}

The social criticism of literature has, no doubt, been practiced more widely than it has been recognized as a theory. With the more or less unconscious practice of such criticism, however, this book does not attempt to deal. It is concerned solely with the explicit theory of social criticism and with the development of the conception of literature underlying it, which has "come to consciousness" either partially or wholly in various writers about literature, since the time of Plato. Some of these writers have been noted in the following pages, but only such as seem best calculated to illustrate the conception or some phase of its development. A complete history of the genesis and evolution of the social theory of literature remains to be written, when the theory itself is more fully understood. As a contribution towards its fuller understanding, this little book is offered. Its purpose will be achieved, if it shall succeed in clearing the ground for further study of the social theory of literature, by presenting its relations to other critical theories and defining certain of its more obvious implications, both speculative and practical.

Gfateful acknowledgment of my indebtedness for light upon this subject is due to Professor Fred Newton Scott, of the University of Michigan, 
whose courses, more. than twenty years ago, explicitly recognized the social significance of literature and inspired his students to further investigation of this significance; to Professor Laura Johnson Wylie, under whose leadership every course in English at Vassar College is animated by the social conception of literature; to Professor John Dewey, of Columbia University, whose philosophy of society has directed all my thinking about literature; and, finally, to my students in Literary Criticism, who for many years, attacking its problems with me, have stimulated and clarified my understanding of them.

G. B.

Vassar College, September 18, 1916. 


\section{CONTENTS}

PAGE

Preface . . . . . . . . . . . $\mathrm{v}$

Chapter I The Muddle of Criticism . . 1

Chapter II The Larger Criticism . . . 16

Chapter III The Standards of Criticism . 33

Chapter IV The Function of the Critic . 47 



\section{'THE SOCIAL CRITICISM OF LITERATURE}




\section{CHAPTER I}

\section{THE MUDDLE OF CRITICISM}

By simple folk in every age literary criticism has been accounted only a more pretentious name for finding fault with what one reads. All authorities, past and present, agree in ruling out of court this untutored definition; but when an accredited substitute for it is demanded, the hitherto unanimous voice of critical doctrine breaks into a jangle of dissonant statements. The flippant will have it that criticism consists chiefly in anecdotes concerning Johnson's tea and the love-affairs of Shelley. By no means, protest the philological. Rather is it the textual emendation of Chaucer. It is nothing, urges the old-fashioned scholar, if it be not the principles of poetry delivered unto us by Aristotle.' No doubt, asserts the pedagogue, criticism is the English teacher's use of red ink on a pupil's theme. The historian of literature finds his conception of criticism exemplified in Gilbert Murray's study of the folk-lore connected with the plot of Hamlet; the apostle of "general culture," in Arnold's cryptic enthusiasms over a passage from Homer or Dante.

Which of these diverse meanings is the bewildered reader to affix to the term "criticism" when 
it meets his eye in some literary essay? The writer may have had in mind any one of the foregoing conceptions of the term, or any one of a dozen others. Only the hard-worked context could possibly determine which, unless, indeed, a saving adjective has been prefixed to the general term. Accordingly such adjectives have been called to the rescue, and we read of scientific, and of historical literary criticism, of criticism deductive and inductive, comparative, appreciative, impressionistic, æsthetic and social. ${ }^{1}$ But even these apparently definite terms refuse to yield immediate enlightenment. Mr. George Saintsbury, himself a distinguished advocate and exemplar of comparative criticism, protests, almost with tears, that while he has "gravely and strenuously endeavored to ascertain from the writings both of foreign critics . . . and of their disciples at home, what 'scientific' criticism means," in no case has he "been able to obtain any clear conception of its connotation in the mouths or minds of those who use the phrase." 2

The case is not, however, for most of us, quite so hopeless as this. The fundamental distinction between judicial or deductive and scientific or

$1 \mathrm{Mr}$. R. G. Moulton, who gave currency to the term "inductive criticism," has also added "speculative criticism" to our nomenclature. See ch. $\mathbf{x}$ in his Modern Study of Literature.

2 Essays in English Literature, 1780-1860, pp. xi-xii. 
inductive criticism has long since been broadly established on the lines suggested by their respective names, the former basing itself on accepted principles, the latter on tested facts. Deductive criticism, we are invariably told, both by its partisans and by its assailants, stands firmly upon some accredited canon of literature, such as, to take an extreme instance, the "three unities" of drama. Applying this canon to, say, The Two Gentlemen of Verona, a critic of the deductive school must conclude that the construction of this play is faulty. Inductive, historical or scientific critieism, on the contrary, turning its back upon all accepted principles, sets out to discover certain facts about this same play,-such facts, for instance, as its probable date, different printings and performances, changes in the text, the sources of various elements in the plot. These facts must often lead to certain inferences, but not, it must be noted, inferences as to the value of the play. Scientific criticism, in its furthest recoil from judicial criticism, would confine itself to accounting for a given piece of literature, steadfastly refusing to evaluate it. In so doing it explicitly challenges the claim of judicial criticism that the literature of past ages, from which the latter's standards are necessarily drawn, should fix values for the literature of the present and of the future; and sets up a conception of literature as perpetually growing and changing, a creature of 
organic development, not of fixed, inorganic structure.

Out of such a conception, however, logically arises a new standard of judgment for particular pieces of literature. Those scientific critics who, like $M$. Brunetière, insist that the judgment of a work of art is an essential part of the process of criticism, imply, as a basis for this judgment, the accurate "placing" of the piece of literature in question in the development of a particular type or period. The ultimate question for such criticism is not: "Does this play follow the accredited literary traditions?" but "How does it further the observed development of literature?"

This observed development of literature, moreover, gives rise to a new conception of the laws of literature, which scientific criticism recognizes not as laws in the legal, mandatory sense of the word, but rather as "statements of the habits", of ballads and essays, declaring not what ought to be, but what is. On these points, then,-namely; the right starting point for the critical process, its proper method and conclusions, its underlying conceptions of the nature and the laws of literature,scientific criticism stands, broadly speaking, in point-blank opposition to judicial criticism.

Comparative criticism is essentially scientific in its appeal to a wide reading of related literature

3 R. G. Moulton, Shakespeare as a Dramatic Artist, p. 33. 
rather than to a single accredited model or principle. Yet Mr. George Saintsbury's exposition ${ }^{4}$ stresses its deductive affiliations, not merely in holding judgment of values to be a primary concern of the critic of literature (for, as we have seen, some scientific critics also profess this faith), but in making value apparently synonymous with conformity to accepted classic standards rather than with the furthering of literary evolution.

In this merry war of critical theories, the protagonists of scientific criticism, though largely outnumbering the defenders of the earlier faith, have not held the field unassailed. Mr. Irving Babbitt, in an article entitled Impressionist versus Judicial Criticism, ${ }^{5}$ having roughly classified as either impressionistic or scientific "nearly all recent criticism, so far as it is anything more than a form of gossip and small talk," asserts that neither of these types affords, as does judicial criticism, "any real means of escape from the quicksands of relativity to some firm ground of judgment." He neatly discriminates the types arraigned by declaring that for Taine, the scientific critic, a poem is the result of certain "prosaic facts of environment," while to the impressionist critic it is rather a cause of his own sensations. Impressionist eriticism has no more concern with

4 Essays in English Literature, 1780-1860, p. xxvi.

5 Publications of the Modern Language Association, 1906. 
the process by which a book came into being than it has with a judgment of the book's value. It only revels in the unanalyzed effect produced by the book. When this effect is expressed in words for the benefit of other readers, we have a mere report of the critic's personal reactions to a work of literary art, a recital, in the overquoted phrase of M. Anatole France, of "les aventures de son âme au milieu des chefs-d'œuvre." * This recital may or may not be interesting reading; but neither it nor the report of the scientific critic can have any value as criticism, since neither affords any sure test of the quality of a given piece of writing. The scientific critic, declares Mr. Babbitt, fixes our attention "on precisely those features of a poem that are least poetical. The very prosaic facts he is looking for would be at least as visible in the writing of some mediocrity as in a work of the first order." Or, as Miss Ethel Puffer more picturesquely puts it, "the psychological process in the development of a dramatic idea . . . is, . . . from the point of view of such analysis, exactly the same for a Shakespeare and for the Hoyt of our American farces." ?

And, as for impressionist criticism, Mr. Babbitt is quite sure that a "third-rate bit of contemporary sentimentality will 'suggest' more ineffable dreams

- La Vie Littéraire, 1 serie, p. iii.

7 The Psychology of Beauty, p. 17. 
to the young woman in the long chair than a play of Sophocles," and therefore must, by the premises of impressionistic criticism, be ranked as the better literature! Even the appreciative critic, most closely associated with the impressionist, has opened fire upon his shifting scale of values. "Can criticism," asks Mr. Lewis E. Gates, with portentous courtesy, "properly confine itself to the record of a momentary shiver across a single set of possibly degenerate nerves?" 8

The alleged assumptions of impressionist criticism that the critic's reactions to a piece of literature are more important than the writer's process, and that these reactions are important as being individual, rather than as being typical or representative, have been repeatedly brought to light by its opponents and set up as a plain target for ridicule. By its partisans they have, however, been as often disclaimed. The critic's reactions need not, they assert, be held more important than the writer's process in order to justify any presentation of them, nor does the critic of necessity regard his reactions as of importance primarily because they are his. A sensitive and cultivated mind, however rare, is not unique; and the record of its responses to any work of art must have value as the revelation of what this work of art may

8 Impressionism and Appreciation, The Atlantic Monthly, July, 1900. 
mean to other minds in some degree capable of appreciating it.

The charge of relativity of judgment has never been disproved, because it could not be ; but it is set aside by the fundamental conception of impressionist criticism, which it shares with the more radical body of scientific criticism, namely, that judgment of values in literature is no part of the critical process. Naturally this view is sustained by " appreciative criticism," which, as defined by Mr. Gates, seems to blend scientific and impressionist criticism in the fuller, deeper experience of appreciation. To appreciate a work of art, the critic must have regard to its historical setting and its psychological origin; but we note that his aim in so doing "is primarily not to explain (with the scientific critic) and not to judge or to dogmatize (as does the judicial critic) but to enjoy; to realize the manifold charms the work of art has gathered unto itself from all sources and to interpret this charm imaginatively to the men of his own day and generation." 9

This statement suggests a sentence from the preface by Messrs. Gayley and Scott to their invaluable bibliography of literary criticism: "There are degrees of enjoyment, the highest of which is criticism; as there are of creation, the highest of

- Impressionism and Appreciation, The Atlantic Monthly, July, 1900. 
which is art." 10 And such a conception seems to promise at once a freer and a richer development of the critical process than either facile impressionism or laborious fact-grubbing, taken each by itself.

Miss Puffer, however, finds even this larger notion of criticism incomplete. ${ }^{11}$ It still lacks, as do its component elements, impressionist and scientific criticism, any standard of judgment. Through exact knowledge of the time, the writer, the language, other languages and literatures, one may reproduce mentally the process by which a work of art comes into being, yet have no idea whether it is beautiful or ugly or merely commonplace. One may enjoy a work of art without ever knowing "whence and why" its charm, be moved by it without understanding whether or to what degree one ought to be moved by it. There is need of a type of criticism, latterly styled "æsthetic," a criticism which, disregarding the writer's end of the literary process, shall devote itself to explaining the effects produced by the play or poem upon the reader, and evaluating these effects by reference to established æsthetic laws.

This type of criticism, though newly named, is as old as Aristotle. The ancient critics, however inadequately from the modern point of view they

10 Methods and Materials of Literary Criticism, p. iv.

11 The Psychology of Beauty, ch. I. 
were furnished for such inquiry, had a lively curiosity about the nature and cause of effects produced upon the reader by certain types of literature and certain "devices" of style. In fact the sophistic rhetoricians as represented in Plato's Dialogues and as followed too sedulously by Aristotle, tended to reduce the theory of discourse altogether to analyses of the means employed by the orator to bring about certain desired reactions in the hearer. Although ostensibly aiming to form the effective orator, they were actually so preoccupied with the auditor's thoughts and feelings that what the speaker thought and felt was largely left out of their account. In the Poetics, Aristotle, with no science of rsthetics at command, but with an unequalled power of using his selfmade analytic instruments, essayed to discriminate and explain the peculiar effect upon the reader of tragedy, of metaphor, of "prose poetry" and of other phenomena of literature. Longinus, Cicero, Horace, Quintilian, Hegel, Lessing, Burke, Freytag, and many other critics have investigated similar phenomena to the end of accounting for the reader's reactions and disclosing the laws involved.

But a new reading of æsthetic eriticism has been called forth by the development of modern æsthetic theory, which, even in its beginning, gives us glimpses of possible explanations at variance with those offered by the literary critics of two hundred or even fifty years ago. When Cicero tells us that 
metaphor gives pleasure because it "is directed immediately to our senses and principally to the sense of sight," ${ }_{12}$ we find the reason inadequate. Nor can Burke's assertion that we enjoy tragedy because "we have a degree of delight, and that no small one, in the real misfortunes and pains of others," ${ }^{13}$ bring conviction. In recent years, however, Miss Puffer's own dealings with The Emotions of the Drama and The Beauty of Literature, M. Bergson's chapters on The Comic in Situations and in Words and The Comic in Character, Miss Elizabeth Kemper Adams's The AEsthetic Moment, Mr. Fred N. Scott's The Fundamental Differentia of Poetry and Prose and' The Scansion of Prose Rhythm, offer, for certain aspects or types of literature, explanations and standards of valuation which modern psychology and æsthetics have. not yet rendered obsolete.

Assthetic criticism, then, as the latest claimant to the title of the one true criticism, stands, like all the others, in an attitude of opposition to every other type. Scientific eriticism, as we have seen, condemns judicial eriticism for judging literature solely by its conformity with accepted models or canons; and accuses it of blocking the progress of literature by this procedure. Judicial criticism, on the other hand, distrusts scientific criticism because

12 De Oratore, book III, ch. XL. 13 On the Sublime and Beautiful, part I, section xIv. 
it offers no fixed, external standards of judgment. Impressionist criticism holds both scientific and judicial criticism to be irrelevant to the one essential question: How does this piece of literature affect me, the reader? Scientific and judicial criticism, in their turn, ridicule impressionist criticism as superficial and egoistic. Appreciative criticism will accept the aid of scientific and of impressionist criticism, but sees both as inadequate to reach the final end of criticism, namely, the full experiencing of a piece of literature; while it finds judicial criticism incapable of even starting in the direction of this goal. Asthetic criticism, rejecting all previous types, except deductive criticism, on the ground that they furnish no sure standard of judgment, discredits deductive criticism also, by the familiar declaration that it has only a traditional basis for its conclusions.

We have, thus, in the field of critical theory, at least six warring conceptions of what criticism really is. And to this confusion we must add the prevalent uncertainty as to whether criticism is an act (the act of judging or investigating or appreciating, or what-not), or whether it is rather the written product of this act (Pater's essay on Coleridge or Freytag's Technique of the Drama). These last illustrations, moreover, suggest still another source of confusion, which Mr. Saintsbury recognizes in distinguishing between Aristotle's "criticism" in the sense of critical judgments of 
particular writers or works, and his "critical theory" 14 as exemplified in the Poetics. ${ }^{15}$

Is it possible for the reader of current criticism to adjudicate the rival claims of these as yet unreconciled, though not irreconcilable, conceptions? Is there a central idea of criticism underlying them all, a single process of eriticism to which each of the diverse types is contributory? If so, the discovery of this focal idea or larger process is surely incumbent upon students of critical theory, to whom the hopeless muddle of critical conceptions exemplified by Mr. Saintsbury's omnibus definition of criticism has become intolerable.

Criticism [he propounds] is pretty much the same thing as the reasoned exercise of Literary Taste-the attempt, by examination of literature, to find out what it is that makes literature pleasant, and therefore good,-the discovery, classification and, as far as possible, tracing to their sources, of the qualities of poetry and prose, of style and metre, the classification of literary kinds, the examination and

14 The History of Criticism, vol. I, p. 35.

15 Professor Moulton follows this distinction (The Modern Study of Literature, ch. $\mathrm{x}$ ) in separating "speculative criticism, working toward theory and philosophy of literature," from "inductive" and "judicial" criticism, which aim by different means at the interpretation, classification or assaying of particular pieces of literature. 
"proving," as arms are proved, of literary means and weapons, not neglecting the observation of literary fashions and the like. ${ }^{18}$

Such a heterogeneous, unanalyzed mass of activities seems to have swept together most of the variant conceptions of criticism with which we started, making no attempt to inquire which are essential and what their relations to one another may be. Clear thinking demands that the literary anecdote and textual restoration alike, Aristotle's theory of tragedy and the English teacher's correction of faulty grammar, the tracing of Hamlet to springmyths and the selection of "touch-stones of literature," be either "placed" in the one great activity of criticism or definitely excluded from it; that the essential, all-inclusive elements in this activity appear, freed from irrelevant and confusing detail; that starting-point, method and conclusion of the critical process be adequately distinguished from one another; that the writer's part in the production of literature and the reader's part in appreciating it be equally taken into account; that the various types of criticism be discriminated on a functional basis, the contribution of each type to a larger conception of criticism rightly understood, and the standards of literature implied in each fully recognized. When these things are

16 The History of Criticism, vol. I, p. 4. 
done, and only then, will "the muddle of criticism" be resolved into rational order and the long war of critical theories end in the active peace of coöperation. 


\section{CHAPTER II}

\section{THE LARGER CRITICISM}

One must listen closely to hear, amid the jangle of conflicting theories as to what literary criticism really is, the still small voice of their harmonious relation to one another. Once heard, however, it cannot be disregarded.

Each type of criticism, arising to supplement the inadequacies of previous types, has enriched our conception of the critical process. Deductive criticism as first formulated could furnish no basis for its judgments save traditional authority or the arbitrary personal taste which had, though often unconsciously, been moulded by it. Recognizing the need of a broader and firmer grounding for the critic's conclusions, historic or scientific criticism offered to supply such a grounding in the thoroughgoing study of literary origins and development. This genetic study gave rise to a conception of literature which proved of immense importance to critical theory. In so far as any writing under examination was recognized as an outcome directly of the author's individual experience and training, indirectly of the political, social and industrial order in which he worked, in so far as the influence upon this writing of other writings in many lan- 
guages both of this and of antecedent periods was taken into account, just so far did literature inevi-, tably cease to be for criticism a mere static, rigidly limited thing-in-itself, and become an organic development, rooted deep in human history and complexly interfunctioning with it.

But though scientific eriticism, so to speak, loosened the current conception of literature, and notably enlarged it at the writer's end, a corresponding extension in the direction of the reader took place only when impressionist criticism entered the field. As a result of the attention which this type of criticism directed upon the reader's reaction to a given piece of literature, the epic or drama in question ceased to be for criticism merely an outgrowth from the writer's mind, definitely conditioned by various historic, economic and literary elements in his environment, and came to include also the final flowering in the reader's mind of this deep-rooted growth.

Thus did scientific and impressionist criticism, each supplementing the work of the other, prepare a highway for appreciative criticism, which, not content to occupy merely one section of the great realm of literature thus opened to it, entered into possession of the whole. To the appreciative critic literature for the first time presented itself as properly inclusive of all the phenomena associated with it; and these phenomena were, moreover, for the first time explicitly recognized as 
constituting a continuous activity, comparable perhaps to that of an electric current. Literature, as thus conceived, might be generated immediately in the writer's consciousness and ultimately in the consciousness of his age, but it would complete itself only as it passed over into the reader's consciousness to enlighten or to stir it into action.

The entire literary activity, then, from writer to reader, has been preëmpted for criticism by the appreciative theory. Intensive research into its various stages or sections, however, belongs to those schools whose view of the critical field is more limited. Esthetic criticism, for instance, has undertaken the closer analysis of the reader's reaction according to modern scientific method; and such a contribution can hardly be overvalued. Impressionist criticism had done a needed work in turning the critic's attention to the reader's end of the literary act. This attention could not, however, rest at the point of mere unanalyzed, personal impression; but, continually defining and universalizing every impression by the aid of known æsthetic principles, must finally evolve a genuine æsthetic criticism.

Asthetic criticism points us to the future. It constitutes, however, an integral part of the continuous development of critical theory, by which a larger view of the field of criticism has been progressively gained and a conception of literature suggested which is at once inclusive and active. 
Each successive step in the history of criticism has brought us nearer to this conception of literature, until to the modern student, graduate of all the earlier critical schools, a book consists, not essentially of so many pages of printed paper bound between covers, but rather of certain activities, or, still more strictly speaking, of a single, continuous activity. This activity may, for purposes of analysis, be separated into the writer's action and the reader's reaction; but neither of these can in itself constitute a book. A book is, in philosophic terms, the writer's action transforming itself into the reader's reaction at the point of print. And the printed words thus reduce themselves to a mere sign of this transformation, not constituting literature but only making it possible. Literature as a social activity has not yet completely taken place when a book is printed and bound. It fulfills itself, becomes literature in any practical sense of the word, only in the act of reading.

The act of reading has thus taken on a new dignity, as literature, in the evolution of critical theories, has become a process rather than a product, something that takes place rather than something which has been made. Literature in this sense is no finished material object-a pill to be swallowed by the reader, or a sugar-plum to be eaten by him. Rather is it a great continuous activity, which goes on through and by the reader, 
his participation constituting its final stage, as organically related to it as the writer's function itself.

Thus defined, however, the act of reading suggests close relations with the act of criticism. Through criticism, at least of the appreciative type, the writer's activity is realized or fulfilled, as it is conceived to be through reading. We are, it is true, accustomed to think of reading as one of the simplest mental processes, of criticism as one of the most complex; and, while admitting that the child reads, we withhold the name critic from all but the highly trained scholar. But as the child may become the critic, so may the simple, unanalytic process of reading pass by imperceptible degrees into the furthest reaches of that extremely complex activity called criticism.

The essential character of reading, whether elementary or advanced in its type, is found in no mere perfunctory turning of leaves, but in active participation, however limited it may be, in the experience which the writer would communicate. One reads, in any real sense of the word, only in so far as he thinks the writer's thoughts after him under the stimulus of his words, sees what the writer saw, feels what the writer felt. Hence "the will to read," if one may paraphrase William James's title, an intelligent hospitality of mind, is the first condition of reading, as it is of criticism. Lacking this coöperative attitude, the preoccupied 
schoolboy can no more read than the critic, intent from the beginning on fault-finding, can criticise; while with it no limitations of knowledge or taste can prevent an infinite development of genuine reading and criticism.

Reading begins the process of criticism at the impressionistic stage. The rader cannot but be affected to some degree and in some manner by what he reads and by some means (not always formally "literary") he is bound to convey this impression to other persons. It is true that only in the degree of his training and sensitiveness has the reader's reaction value for anyone else. But this training and sensitiveness are by no means fixed quantities. They develop in and through the very act of reading. In some sense one must, as Ruskin says, in order to read at all, ascend to the writer's level. "If you will not rise to us, we cannot stoop to you." 1 One must approximate the writer's position in order even to begin to read him, but, once begun, the act of reading itself discloses its essential inadequacies. The activeminded reader finds that, in order to think the writer's thought after him, he must, for a time in very truth, be the writer. He must reconstruct the writer's milieu, social, industrial, political, and the writer's individual life as thus determined, or fail fully to apprehend the thought which grew out

1 Sesame and Lilies: Of Kings' Treasuries. 
of and was modified by this particular set of conditions. And he must furthermore know the writer's literary tools, the form with which he worked, its limitations and its possibilities, how far it had been developed when he laid his hand upon it, or stop short of comprehending his view of life as it shaped itself in and through this form. Here it is evident that the gaining of an immediate impression from what one reads has passed into the realm of that "scientific" criticism which amasses data, brings to bear upon the printed page all relevant knowledge, historical, linguistic, psychological, æsthetic, that reading may be the more intelligent, the richer in content, that what the writer would convey may the more perfectly interpenetrate the reader's mind.

Such interpenetration, furthermore, is the indispensable condition of "appreciative criticism," that complete assimilation of the epic or the essay, with all its connotations, which Mr. Gates has painted for us in colors of delight. ${ }^{2}$ And only such complete assimilation of any work of literature into the reader's mind enables him surely to "disengage" as Pater would say, its peculiar "virtue." Otherwise he is bound to miss some element in it, some essential tang or aroma, some fine distinction of tone. Thus qualified, however,

2 Impressionism and Appreciation, The Atlantic Monthly, July, 1900. 
his appreciation has the exquisite precision of line which we associate with masters of eriticism such as Pater himself. Like them our reader can not only reproduce in his own imaginative experience the complex process by which a given poem through the ages came to be, but he can also realize in all its fullness of meaning the almost equally complex process by which it communicates itself to the reader's mind,- - just what its peculiar individual effect is and how this effect has been produced. $\mathrm{He}$ is able, to quote Miss Puffer's words, descriptive of "æsthetic" criticism, "to tell us whence and why the charm of a work of art: to disengage, to explain, to measure, and to certify it." ${ }_{3}$

When he proceeds "to measure and to certify it," however, he has passed out of inductive into deductive or "judicial" criticism. He no longer merely receives, responds, assembles data, compares phenomena and investigates laws, but pronounces upon the quality of the work of literature under his hands. He understands not only how much and why and in what respects he likes it, but how and why and in what respects the intelligent reader ought to like it. And in so doing he has, either implicitly or openly, appealed to certain laws previously discovered in the examination of individual pieces of literature or works of art in other fields. By some body of æsthetic canons in

3 The Psychology of Beauty, p. 25. 
general, or of literary canons in particular, he ranks and evaluates.

The discovery and formulation of these literary canons are a part of the process of criticism, but not necessarily a part of the process of reading, in which theory remains somewhat implicit. That point in the reading-act, then, at which some theory about what is read emerges into consciousness, may serve as the point of departure for criticism, in its more abstract stages, out of the concrete act of reading. A further point, at which this theory is definitely used as a basis for judging particular pieces of literature, may locate a boundary line between the theoretic and the judicial aspects of the critical process. Thus the critic's progress from naïve impression to formulated judgment seems, roughly speaking, to present three primary stages, the first of which coincides with reading, while the second and third ultimately derive from it. Criticism, as we have seen, begins with the reading of literature in the fullest sense of the term, including the gathering together of knowledge from all the various sources which might serve to enrich the understanding of what is read. In this reading certain theories of literature and of the specific types of literature read are bound to come to consciousness, resulting in a more or less formulated body of laws expressive of the modes in which literature has its rise under given conditions, takes particular forms, dêvelops and 
changes these forms or invents new ones, acts in specific ways upon the reader and upon society as a whole. And finally, on the basis of these laws, particular pieces of literature are judged, ranked and classified.

In practice these three stages of the critical process are not rigidly separated fro: ane another, and our nomenclature still leaves them undistinguished. The critical reading and interpretation of literature in the light of all relevant facts about it is eriticism. The formulated body of laws derived from this reading is criticism. And the ranking of particular pieces of literature on the basis of these discovered laws is also criticism. This blanket-use of the term doubtless tends to confusion; and it seems desirable to adopt the selfexplanatory names "critical reading," "critical theory" and "critical judgment" as a means of recognizing three important stages in the act of criticism without denying the essential unity of the act.

The logical order of these three stages is apparent. The term "critical reading" must be applied not alone to the exhaustive analyses of the highly trained and sensitive scholar, but to those simpler and less self-conscious acts of mental assimilation which by the law of their own nature tend continually to deepen and enrich themselves. In a very sober, literal sense it may be asserted that whoever sincerely reads anything-not perfunctorily run- 
ning his eye over the pages but actually transforming the writer's experience into his own-has thereby started on the long path of criticism. Not only does such reading constantly improve itself, becoming more exact in its responses to the stim ulus given by the writer, better informed on all points which full reaction to this stimulus involves, but eventually it yields a body of theory organically related to the literature read, not arbitrarify imposed upon it by some external authority.

It is such a body of theory, inductively derived, which all the protestants against deductive literary criticism, from Coleridge to Mr. J. E. Spingarn, explicitly demand. "We have done with all the old Rules," declares Mr. Spingarn ; ${ }^{4}$ and no doubt we have, in so far as these rules have become purely arbitrary, without vital connection with the works of literature to which they are applied. They can have validity for us today only as they come to consciousness anew in our reading of the more diversified body of literature known to our time, and as a result of the more exact psychological and æsthetic analysis for which we are now equipped. There is, of course, no doubt that an adequate theory of poetry, for instance, would ultimately be serviceable to the critical reading of poetry. This fact cannot, however, be allowed to obscure the more important principle that such a theory, in

4 The New Criticism, p. 20. 
order to be thus serviceable, must presuppose an extended reading of poetry and arise out of it.

As for critical judgment, once apparently the sole interest of critics, it no longer both begins and ends the process of criticism. Instead of standing at the entrance of the critic's course, with an effect of blocking his progress, it follows upon a prolonged activity of critical reading and a ten. tative formulation of critical theory, so that it seems rather to reward his labors than to render them unnecessary. Built thus upon human study and reasoning, it loses its oracular quality, its unquestioned finality, and takes on the more useful aspect of a conclusion formulated for the present on the basis of what is now known, and serving merely as a stepping-stone to some further knowledge or understanding.

Such a conception of the process of criticism, far less authoritative than the old, but compensatingly richer and more organically related with the process of literary creation, must serve as basis for classifying the products of eriticism. These, multitudinous though they may be, readily group themselves under the three headings, critical reading, critical theory, and critical judgment. Of these the second group is most obviously distinguished from the others. That stage of the critical process in which theories of literature come to consciousness leaves behind it systematic treatises such as Aristotle's Poetics and Freytag's Technique of 
the Drama. Critical reading, having collected historic and textual data to its own ends, may give them permanent, though usually unliterary, form in annotations, emendations, detailed comparisons and summaries of evidence upon disputed points. But critical reading in its less pedestrian realms, and critical judgment as growing out of it, yield the richest harvests of critical literature.

When Matthew Arnold declares that criticism consists in "a disinterested endeavor to learn and propagate the best that is known and thought in the world," s the verb "to learn" suggests that vital assimilative activity of mind which we have termed "critical reading"; while its correlative "to propagate" lays hold of that creative product of the critical process which Arnold's own literary essays aptly represent, The writer who brings "a new piece of literature into being in some exquisitely happy characterization," creates "a lyric of criticism out of the unique pleasure of an æsthetic hour," "propagates in other minds "the best that is known and thought in the world,"-merely carries over to these minds his own experience of that critical process which we have previously analyzed. Implicit or apparent in many of the literary essays of Arnold we find all the salient elements of the complete critical activity,- the inquiry after such

- The Function of Criticism at the Present Time.

- The Psychology of Beauty, p. 3. 
data as may presumably enrich the act of reading, the full, vital interpenetration of the given book or writer with the eritic's mind, the discovery, or at least the re-formulation, of certain laws of literature, the judgment of writer or book on the basis of these laws. Critical literature is, then, the final flowering in a creative literary act of the critical process, either in part or as a whole.

Through critical literature, critics of every school may contribute to the common stock their knowledge and understanding of literature in any of its aspects or relations. In an essay on The Higher Study of English, Mr. Albert S. Cook enumerates some of the possible activities of the scholarly critic :

According to the exigencies which circumstances create, or his own intuition perceives, he will edit dictionaries, like Johnson or Murray; make lexicons to individual authors, like Schmidt; compile concordances, like Bartlett or Ellis; investigate metre, like Sievers or Schipper; edit authors, as Skeat has edited Chaucer, Child the English and Scottish Ballads, and Furness Shakespeare; discourse on the laws of literature, like Sidney, or Ben Jonson, or Lewes, or Walter Pater; write literary biography, like Brandl or Dowden; or outline the features and progress of a national literature, like Ten Brink, or Stopford Brooke, 
or Taine. . . Y Yet withal he must be content, if fortune, or his sense of a potential universe hidden in his apparently insignificant task, will have it so, merely to settle hoti's business, properly base oun, or give us the doctrine of the enclitic $d e$-sure that posterity, while it may ungratefully forget him, will at least have cause to bless his name, as that of one without whose strenuous and self-sacrificing exertions the poets, the orators, the historians, and the philosophers would have less completely yielded up their meaning, or communicated their inspiration, to an expectant and needy world. ${ }^{7}$

Plainly, as Mr. Saintsbury declares, "The life of Methuselah and the mind of Shakespeare together could hardly take the whole of critical knowledge to be their joint province." 8 But the many members are one body. To assign them relative values is not only an ungracious but an impossible task. "If they were all one member, where were the body?" Not the particular section of the critical field which is tilled, but the efficiency of its tilling determines the critic's value. Every type of critical activity is indispensable-one might almost say equally indispensable - to the great process of criticism. But each type can reach its highest effective-

${ }^{7}$ pp. 22-3.

8 Essays in English Literature, 1780-1860, p. xix. 
ness toward the ends of the process as a whole only in so far as it becomes intelligently aware of these ends. Sound perception of what criticism in its largest reaches aims to achieve makes even "hoti's business" and "the doctrine of the enclitic $d e$ " a genuine help to our reading, instead of mere academic pottering, redeems impressionist rhapsodies from their accustomed trivial finality to fruitful suggestiveness, and teaches the critic of every school sincere gratitude to the many workers who in all ages have added even a little to our vital understanding of literature.

Recognition of the larger whole of criticism restores the seamless robe which partisanship and intolerance have rent in shreds. From the wars of critical theories, each too limited in its outlook to recognize its coöperative relation with all the others, the modern critic has emerged with one priceless possession-a vitalized, democratized conception of literature. To him a book can never again be a barren, finished product, a scholastic abstraction, but a living activity of more than writer and reader, a genuine function of the social body. This inconceivably precious idea he as yet hardly knows how to value or to use. Rightly used, it should solve, by its fundamental analysis of their factors, the age-old, baffling problems of criticism which previous partial or artificial conceptions of literature have succeeded only in restating. But such thoroughgoing solution 
awaits a more complete realization than has yet been generally attained of the length and breadth and depth and height of this epoch-making idea. When the modern critic knows,' not as a mere formula, but with full realization of its as yet quite incredible implications, what literature as a social function may be, the larger criticism will also have become the deeper criticism, penetrating to the innermost meaning of our literature in its relations to our life. 


\section{CHAPTER III}

\section{THE STANDARDS OF CRITICISM}

The practice of criticism has, in many directions, profited incalculably by the long development of theories of criticism throughout the ages of men's dealings with literature. One practical demand upon eritical theory, however, yet remains unsatisfied,- the demand for a standard of judgment.

The standard of traditional authority which deductive criticism offers has been definitely rejected by modern critics. All but universally it is recognized that such a standard stultifies both eriticism and literature. It substitutes a mechanical coercion for the living interconnections of criticism with literature, reduces the critic to an automaton while exalting him to a despot, and artificializes literature, by cutting it off from organic relation to its own time.

Scientific criticism, of the extreme "inductive" school, reacts, perhaps immoderately, from this tyranny of the deductive standard, by denying to judgment any place whatsoever in the act of criticism. This seems, indeed, to throw out the child with the bath. It should not be necessary to repudiate all measures of value, in order to do away with those arbitrary and external standards which 
have no vital relation with the writings to which they are applied. More penetrating thinkers, of the type of Coleridge, recognize this fact, and, as Miss Laura J. Wylie has pointed out in her Evolution of English Criticism, ${ }^{1}$ stand with the romanticists not only in rejecting standards imposed from without upon art, but also in conceiving of the laws which have present validity for literature as essentially organic, because derived from the writings in question rather than from the classic models. Even Coleridge, however, fails to indicate precisely what laws or standards they are which may be thus derived from the work of literature itself. Nor do modern critics of Mr. J. E. Spingarn's way of thinking greatly further our search by insisting only that we apply to the writer "no other standard than that applied to any other creative artist: what has he tried to express, and how has he expressed it." 2 Such a test fixes for us what Mr. Gates rightly denominates the "intended value" of a book, but leaves undetermined its actual value, which may be quite outside the writer's calculation.

It seems plain that this actual value cannot be determined by standards derived from the book regarded merely in its relations to the writer or to the conditions under which it was produced, since the book, considered as a whole, involves relations to

1 p. 184.

2 The New Criticism, p. 28. 
the reader as well. Miss Ethel Puffer implies this larger view of literature in her contention that the "placing" of a book in the process of literary development, which $M$. Brunetière insists upon as an essential part of historical or scientific criticism, does not necessarily involve any judgment as to the value of the book; since "the judgment of anything always means judgment with reference to the end for which it exists," ${ }^{3}$ and scientific criticism takes account only of the conditions under which literature arises.

Mr. Saintsbury vehemently reproaches scientific criticism for failing to supply us with an dequate standard for judging literature, but he bimself suggests no such standard, nor apparently makes practical use of any except the traditional canons. In fact, it may be said that comparative criticism, in so far as it admits the conception of relative values, determines them by the old-fashioned rules, while in so far as it confines itself to "placing" a given piece of literature in the process of literary development, it is satisfied with the partial standards of scientific criticism.

Impressionist criticism cannot fairly be assailed for affording us no basis of judgment, since it joins with some scientific and most appreciative criticism in denying the need of any such basis. Mr. Gates, however, speaking for the appreciative critic,

3 The Psychology of Beauty, p. 8. 
admits that even "in his search for the pleasure involved in a work of art," he "finds that he must go outside the work of art and beyond his own momentary state of consciousness; he must see the work of art in its relations to larger and larger groups of facts." And such an admission seems significant not only because it decisively rejects the impressionist's purely personal and relative attitude toward literature; but because it suggests the possibility of seeing a work of art "in its relations to larger and larger groups of facts," until, at length, all its relations are taken into account and an adequate basis of judgment has thus been gained.

Asthetic criticism stands with deductive criticism in definitely recognizing the obligation of critical theory to furnish a sure test of values. It stands with all the other types, however, in discrediting the deductive test. The æsthetic critic cannot as yet provide us with a usable standard in its place; but Miss Puffer gives us to understand that æsthetic theory will supply our need, once it has fully entered into its kingdom. The æsthetic critic is needed, she declares, to "teach us what great art means in literature," to tell us "what a novel ought to be," so that "we shall not always mingle the wheat and the chaff."

Impressionism and Appreciation, The Atlantic Monthly, July, 1900.

5 The Psychology of Beauty, pp. 25-6. 
This is the fairest promise we have had, and we may, I think, trust it, so far as the province of æsthetics covers the field of literature. Understood broadly the term æstheties might include even those subtler intellectual and spiritual reverberations in the reader which Mr. Gates insists on taking into account. No scientific methods as yet devised, or in immediate prospect, can, it is true, measure them. But this is not to say that such measurement is inherently and ultimately impossible.

Modern critieism stands ready to welcome any achievement in this direction. But meanwhile it must make sure that the Targer conception of literature is not reduced to such a conception as our present æsthetic science is qualified to deal with,the conception (shall we say?) of literature as some piece of verbal apparatus, cleverly designed to produce certain reactions in the reader. This would be to renounce the spacious territory won by criticism through many generations, to drop out of account the writer's end of the literary process, to ignore our slowly clearing and strengthening sense of literature as a great social activity and institution.

This sense of literature we have seen evolving by gradual and chiefly unconscious stages as successive schools of criticism have perceived more clearly the great factors in their problem. But in a crude form the social conception of literature antedates all 
modern schools of criticism, since it was specifically implied in Plato's much-derided exclusion of the poets from his ideal state, on the ground that they indulge the feelings and enfeeble the reason of man. ${ }^{6}$ Literature is a social institution. Plato in effect affirmed, and as such must be judged by social standards. That the nature and function of poetry were but imperfectly understood by Plato does not destroy the significance of this early suggestion, though it has often prevented modern critics from recognizing its significance Nor can any later restrictions of the principle to crudety moralistic ends destroy its wider

Mr. Arthur Ransome has lately remterpreted the battle-cry, "Art for Art's sake," which was raised against the domination of moralistic and naturalistic standards in art, into the theory of "Apt-for Life's sake." " But the second phrase merely substitutes a truer, that is, a more social, conception of morality for that implied in the bourgeois censure of art. Art exists not for its own sake, not for the sake of nature, or even. for the sake of morals, - not, indeed, for any sake smaller than that of life itself. To heighten the poet's consciousness of life, and to "enrich the blood of the world" by offering to his readers "opportunities of conscious living," Mr. Ransome

- The Republic, $\mathbf{x}$.

7 Portraits and Speculations, p. 1. 
defines as the twofold function of poetry. And this is essentially a social function. The poet's intensified consciousness is transmitted to the reader, who receives from it an access of life, whether in the form of perception, emotion, or what-not. Wherever this transfer takes place society is at that point leveled up to the poet. The poet's individual gain in perception or emotion has been socialized.

Twenty years ago, Edward Rowland Sill, in an essay called Principles of Criticism, proposed as a test for literature its "life-giving power" and further analyzed this test, as follows:

It is not enough that a picture or a novel or a poem should move us : the question is, What does it move in us? How much of the whole possible range of our inner life does it awaken? Nor is mere intensity of impression any suffcient test. For one must inquire, Whither does this tend,--toward further renewal of full existence, or toward reaction and stagnation? Some feelings are kindled only to smoulder away and leave dead ashes; ... others tend to kindle on and on, awakening thought, rousing to vigorous action. Nor are the most easily moved activities always the most important ones in the effect of art and literature. . . . It is the great motive powers deep down in the soul that most contribute to 
abounding life, and whose awakening most surely proves the presence of genius. ${ }^{8}$

It is unlikely that $\mathrm{Nr}$.Sill recognized the precise relation of this suggestion to previous theories of criticism or wolly perceived its soctat significance. But this relation and this significance are platn to the reader of today. Perhaps the fundamental conception had been drawn from Matthew Arnold's Function of Criticism at the Present Time, which in its recognition of the critic's duty to "propagate the best that is known and thought in the world" states by implication the social function of literature. The critic, in Arnold's theory, is the intellectual middleman of the social order, distributing ideas from producer to consumer; but with the ultimate purpose of transforming the capable consumer into a producer. The "current of true and fresh ideas" set in motion by the critic swells the song of the poet, otherwise mute in a stifling atmosphere of practical life. From poet to critic, from critic to readers, from readers to new poets, passes the divine afflatus, in a self-perpetuating cycle. And thus society periodically catches up with its leaders, only to cast forward in the stream of its own progress new leaders whom it must overtake.

Witerature, then, regardert from tho social point of view, is a primary means by which the race advances. The critic's function is to further this

The Prose of-Er. R. Sill, pp. 161-2. 
advance by faeilitating the interaction of literature with society. Wherever literature can directly and completely socialize its ideas, it does so. Where this is difficult, or delayed, the critic mediates. Having read a book, in the full meaning of the term, having gained some view of it or some knowledge about it which may conceivably enrich the reading of others, he communicates his experience to them, in order that the writer's thinking may the more completely interpenetrate their minds, and thus raise them to the writer's level.

Part of the critic's experience with the book has been his judgment of it as worthy of such communication, as in some respects and in some degree valuable to society. In this sense he may be said to regard it as "the best that is known and thought in the world"; the best, that is, not absolutely, but at this moment for himself and for the readers he addresses (who are presumably at approximately his own stage of development), the best calculated to satisfy their perhaps unrecognized needs, and to carry them a step beyond their present experience or powers. If it is too far in advance of them to draw them to its standing-ground, or if it is only abreast of them, to say nothing of lagging behind, it has no function to perform for them as individuals or as members of society, and it is not therefore for them the best, or even good, literature. Good literature, as judged by the social standard, is that which efficiently performs the 
function of literature for any individual or for any group of individuals, namely, the function of making common in society all peculiar advantages of mental endowment or experience.

Such a standard of literature will, it is apparent, yield us no immutable five-foot shelf of "the best books." Nor is this, I take it, what the reiterated demand in the history of criticism for an absolute standard of values means. A book that is "good literature" in the social sense for one reader or for one community may not be good for another. But it is good for each reader and for each community in the degree in which it furthers

(x) $x$ This means that, as Coleridge insisted, the standard by which we judge the book is inherent in the book itself; but not, we must remind ourselves, in the book as a thing printed on sheets of paper and enclosed between covers. The book, from which we are to derive its own standard of value, is the book regarded as a coöperative activity of writer and reader, to the end of the reader's heightened social consciousness. In so far as this activity (the book) achieves its end it is good literature. Like a social standard of value in expenditure, which would affix one value to opera tickets for a given person in a particular situation, and another for a different person in a different situation, but still remains the same standard, the social standard of value in literature marks what we roughly call the 
same book, high for one person at one time or in one set of conditions, low for another person at another time and in other conditions, while the standard itself fluctuates not at all. In the case of the high as of the low estimate, its unchanging basis of judgment is the social efficiency of this cooperative activity of writer and reader, whose visible symbol is the printed book.

For the measurement of this efficiency no methods have as yet been suggested, no instruments devised. The social values of literature cannot at present be stated in kilograms or in degrees Fahrenheit. But the frank recognition of such values, as legitimate material for critical judgment, and the open-minded investigation of them, must ultimately evolve an adequate procedure, which shall take account not of one section only of a literary act, but of the entire act, arising out of a given social situation, focusing itself, say, in a single poem of a single writer, communicating itself to the mind of a single reader in a different social situation, and thence throughout that social situation, modifying it both in obvious and in all but imperceptible ways. This view of literature as a living present activity, not the product of a past, finished act, is to any judgment of its social value. And the thoroughgoing acceptance of this view means to the criticism and to the creation of literature more than any of us can possibly imagine. 


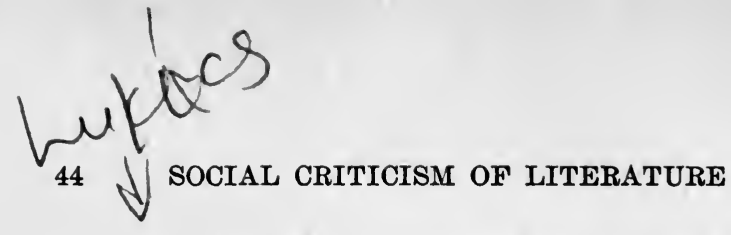

If the value of literature is first and last a social value, any writing which serves the social ends of literature must, in its degree, be accounted "good literature." The realm of good literature thus ceases to be an aristocratic preserve and becomes coextensive with all that is really literature. Even "our trashy, ephemeral, modern writing," to which the old-fashioned critic's resounding scorn would deny all value, may, however crude and unpleasing to him, have something to offer those whose thought and feeling are still more elementary.

But only if it be a sincere expression of the writer's mind. For without sincerity no writing can be good literature; it cannot, in the social sense, be literature at all,-as a counterfeit banknote is not really money:- Literature, according to premise, is the thinking or feeling together of the writer and the reader through the agency of the written word. If, however, the word does not convey the writer's real thought and feeling, the reader cannot think and feel with him by its means, but will simply entertain a thought or a feeling which the writer for some reason wishes him to entertain.

The result of such pseudo-communication is, therefore, not to "level up" the reader with the writer, but to give the writer that advantage over the reader which his writing has, consciously or unconsciously, sought to gain. The process is as distinctly anti-social in its ends as the process of genuine communication is social. It is, properly 
speaking, not literature, but a commercial substitute for it, which the critic is bound to detect and to expose.

Given the indispensable quality of sincerity, then, any writing may for certain people at a certain stage of development, be good literature. As to the other rhetorical virtues, simplicity, elegance, restraint, vividness, force and the rest, it cannot yet be affirmed in how far any or all of them impart to a book the power of quickening and deepening the reader's conscious life. Doubtless one day we shall have a "new rhetoric" which will attempt to estimate in social terms the literary value of these qualities. But these have to do with degrees of excellence, and the social standard has not yet been applied beyond the first critical categories. For the present we must be content merely to substitute for the old personal distinction between "good" literature and "poor," the new social distinction, and to know that degrees of excellence must ultimately be recognized on this same basis. Since literature, though the greatest among us, is as one that serveth, it can be measured only by this service, never by the external signs of editions de luxe or a place "in every gentleman's library."

This social standard of criticism is the standard for which criticism throughout its long history has been searching, and for lack of which each type of eriticism has been found inadequate. It is not a moral standard, in the narrow sense of the term; 
it is not an æsthetic standard in the superficial sense of the term: it is a social standard in the sense which deepens æsthetics and extends morality, - a sease best represented, perhaps, by the phrase "Art for Life's sake."

Such a standard the criticism of two thousand years has slowly fashioned into crude and but halfapprehended form. For the criticism of the future remains the task of recognizing its unimagined implications, defining it more clearly, testing it at every point and applying it to the literature both of the past and of the present. 


\section{CHAPTER IV}

\section{THE FUNCTION OF THE CRITIC}

No longer is the critic regarded as an oracle, enunciating infallible judgments of literature ${ }^{1}$ by an easy comparison of any given book with certain accredited models or by an equally mechanical application to it of rules delivered unto us by Aristotle. We know him rather as a reader like ourselves, dealing with literature as we all deal with it, only carrying the process somewhat further. His dealings with it may be infinitely laborious and prolonged, but we are sure that they can be fruitful for himself and for others only as they are rooted in genuine reading and tend to make it continually more intelligent, more sensitive, more actively coöperative with the writer.

The critic's reading, then, like that of ordinary mortals, must be a process indefinitely progressive. It will continually arrive at valuations of particular books and authors, but must never regard these

1 Mr. John Galsworthy, in Vague Thoughts about Art, plays "with a light pen" about this ancient superstition of the infallibility of the critic. "I have not," he declares, "the firm soul of the critic. It is not my profession to know things for certain, and to make others feel that certainty. On the contrary I am often wrong-a luxury no critic can afford." 
valuations as having, even for the critic himself, more than a present validity and a relative truth. His childish estimate of The Swiss Family Robinson probably differs widely from his grown-up verdict upon it. But his second judgment is not necessarily a truer judgment than the first, nor the first than the second. Each opinion, if indeed it is not a mere parroting of other people's ideas, but honestly his own, is as "true" as the otherand no truer; since each precisely records the value of the book to him at a given stage in his development.

Each opinion thus becomes to him, not a final truth in which to rest, but a point of departure for further reading and criticism. Any reader's ultimate capacity to appreciate literature depends far less on what he may think of a given piece of writing, than upon his really thinking something definite about it; for the recognition either of a book's value or of its lack of value for him increases his power of reading the next book intelligently; and this perpetual progress is essential, while one starting point or another is relatively immaterial. That he should reach a "right" conclusion, so-called, about a particular piece of literature, is, then, no such weighty matter as previous criticism would have us believe. Social criticism would insist only that he should honestly reach such a conclusion as he can reach, and then make each conclusion a stepping-stone to some further judgment, either of 


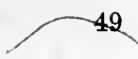

this book or of another. Value thus inheres, not in the judgment itself, but in the whole process of arriving at it and proceeding from it-that is, in the vital and continuous contact with literature which makes it literature indeed.

This continuous personal reaction upon literature, if supremely important for the critic, is no less essential to the general reader; and the critic can be of real use to such a reader, not by saving him all trouble of reading and of thinking about what he reads, but rather by furthering these activities of his in every possible way.

How the critic should proceed to this end is not at once evident, but it may perhaps appear more clearly once we have eliminated the time-honored method of imposing arbitrarily upon the reader the critic's opinions about books. On this point social criticism finds itself widely at variance with previous theories. For generations the schoolboy has been taught that Paradise Lost is good literature because all great critics have so rated it. The troublesome question, how we shall determine who the great critics are, by what standard we are to judge their claim to decide these matters for us, has been placidly put aside by the reiterated declaration that, "after all," those best fitted to fix values in literature must do so and every reader must recognize the values thus fixed.

This is the favorite and most persistent fallacy of criticism, but it is, none the less, a fallacy. 
Holding the critic's opinions to be obligatory upon other readers is very like "fiat money" - easy to issue but sometimes harder to realize upon. No power on earth can make a book really valuable to me if it is not so. Taking bodily over into my consciousness some critic's dictum that it is great literature gives it no fructifying power in my experience. Such a dictum can serve me only in so far as I use it to challenge or to clarify my own critical activity, which may ultimately lead me to a conclusion quite diverse.

Because literature is nothing at all to any individual if it does not become his personal experience, the criticism of literature cannot, in any sense or to any degree, be vicarious. Literary judgments are as essentially individual as the standard on which these judgments are based is universal. While it is true that a standard is no standard if it be not universal, it is equally true that a judgment is no judgment unless it is the culmination of an individual critical activity.

If the benevolent authority of the critic cannot legislate value for other readers into the books he chances to prefer, on the same principle it is powerless to deprive of value all writings which he, by an individual or by a class standard, must grade as "poor." Though these writings may have for him and for those who have reached his stage of development no gift of more abounding life, they are not therefore necessarily incapable of 
bestowing this gift upon any other human ereature. From the social point of view a book which enables any person to see even a little more clearly than he has seen, to think more justly than he has thought, to feel more deeply than he has felt, thereby demonstrates its right to exist and to be read.

The critic's first duty is no doubt to be a good reader and thus to reach certain conclusions as to the value for him of the literature he reads. This duty has been abundantly recognized by all previous theories of criticism. But a new commandment has been given by social criticism, namely, that the critic, having reached these conclusions for himself, shall then hold them as essentially tentative and personal, not only refusing steadfastly to impose them upon other readers, but giving no sanction to their use by any reader as a substitute for his own eritical activity. This is indeed a hard saying, for the critic as well as for the reader; and it can be fulfilled by the critic only as he definitely acknowledges his primary obligation to help, not hinder, the reading of others.

In admitting this obligation, however, the critic by no means abrogates all his powers and resigns all his responsibilities. As a matter of fact he gives up nothing that he ever really had. The critic who renounces every attempt to enforce his judgments of literature upon other people thereby 
parts only with the shadow, not with the substance, of authority. Paradise Lost never really became great literature to any schoolboy, merely because some critic had asserted its claim to the title. Such an assertion may, indeed, help one who has never cared to read the poem or one who has read it without interest to find some value in it for himself, but this can happen only if, refusing to accept the critic's dictum and to regard the case as by that dictum closed, he insists on submitting it to the test of an active-minded personal experience.

To make his expressed judgments of books thus provocative of genuine reading rather than in any degree a substitute for it is the aim of the modern critic. And to incite to an act of genuine reading is a great service, since such reading, as we have seen, tends continually to disclose and to supply its own inadequacies. But the critic may offer further aid in making the reader more acutely conscious of the defects in his own reading and of the means of remedying these defects, by presenting before him in the concrete form of critical essays a full, rich, personal experience with literature.

This full, rich, personal experience of literature may involve many distinct elements-not only a lively first-hand impression of what is read, but a patient accumulation of all the facts which can substantiate or refine this impression, a conscious 
recognition of whatever theories of literature or of particular types of literature may be involved, as well as a tentative judgment of the book in the light of these theories. The presentation to the reader of any or all of these elements should serve to stimulate and clarify his reactions to literature, should help to make him a better reader.

This, then, is the peculiar function of criticism, apart from its function as literature. Because the critic is a writer, he does, as Arnold declared, act as the middleman of ideas, disseminating throughout society "the best that is known and thought in the world," which might otherwise be inaccessible to many people. He gives ideas publicity, makes them more widely available. But this, it must be remembered, is the office of literature in general, not of criticism in particular.

Arnold's own definition of poetry as a "criticism of life" seems to justify the distinction that poetry (and thus perhaps all so-called "creative" literature) deals with "life," that is, with the writer's experience outside of books, as criticism deals with his experience in the field of literature. But this distinction is not clean-cut. The section of our experience which we call books so interpenetrates the section of our experience which we call "life" that a line of demarcation is extremely difficult to draw. What the poet may have read infallibly enters into his poetry, as what the critic 
has known of life at first hand invariably conditions his reaction to books.

The value of Arnold's definition perhaps lies rather in its suggestion of a unity of process underlying the two apparently diverse literary products, poetry and criticism. All literature, it would seem to say, communicates the writer's experience with something,-a book, a woman, a scientific observation, the death of a dearly loved friend, a mountain peak at dawn, an abstract idea. It gives us, if you like, his "criticism" of that something, in the sense that poetry is a criticism of life. But this is only saying, after all, that poetry is literature, as Arnold's parallel statement that criticism distributes ideas throughout the social order declares only that criticism is also a form of literature.

In so far, then, as he is a writer, like the novelist or the poet, the critic's function is, no doubt, to heighten the reader's conscious life by sharing his reactions with him. But as peculiarly a critic, his function is something more specific,-namely, to heighten the reader's conscious life by increasing his capacity to read.

And this means that, in the measure of his success, he makes literature count for more in the lives of individuals, hence for more in the social order. He does not, in his specific function as critic, create-the power of literature, bit only multiplies it, by furthering the interaction of litera- 
ture with society. He studies this interaction at various points as a biologist studies the interplay of an organism with its environment; and takes what means he can devise to increase the efficiency of the process.

One important means of increasing the efficiency of literature's interaction with society is to render this interaction more intelligent, better aware of its own ends. To promote in readers a truer conception of what literature is and does, thus becomes an essential part of the critic's work. A reader who understands the place of literature in the social economy cannot relegate it to the category either of private yachts or of ward politics, but must definitely take account of its relations to himself.

If he chance to be of the large class which prefers the current best seller to Henry Esmond or The Egoist, he need no longer apologize for his tastes to those who regard them as low. Once he clearly perceives the functional value of any genuine act of reading, with whatsoever book it may be connected, his dealing with the literature he can read in this way will cease to be a somewhat shamefaced playing with toys, and regain its rightful dignity, its whole-heartedness and, consequently, its power of development.

Such a reader will not feel it necessary either to pretend to share other people's preferences for the classic writers or to scorn these writers as 
"high-brow." Recognizing the fact that the great literature of past ages, like the popular writing of the present, belongs to readers whose conscious living it has power to quicken, and to such alone, he will not overlook the equally important truth that the real, that is, the social, value of literature depends primarily not on what is read, but on how it is read. He may thus venture to respect his own tastes, not, indeed, as representing any final attainment, but rather as the record of a constant advance in his powers of reading; and is thereby delivered both from the false shame and from the false pride which seem most effectually to bar this advance.

On the other hand, if our reader chance to be of those to whom the high qualities of our classic models are really precious, and who hold the democratic theory of literature responsible for the loss of these qualities from the popular, machine-made, commercialized writing of the present day, his relations both to ancient and to modern literature may be rendered more intelligent by applying to each the social standard of values. Such an application should not only increase his toleration for the modern books he may not care to read, but also distinguish for him the legitimately popular from the wholly commercial writings in this class. And it will assuredly enable him to read his ancient favorites with a fuller appreciation, because he 
will thus have gained a richer sense of their actual relation to the social order of their own time.

The censor of modern writing is often inclined to regard the critic's function at the present time as that of holding aloft a stainless banner of personal taste and dragooning all the world to follow where it leads. Apparently such a view fails to recognize the issue as educational rather than militant. The critic cannot coerce. Books which a cultivated taste considers deplorable are bound to multiply without permission from him, so long as they are read. And they must continue to be read while readers remain below the level of feeling and of thought which these books represent.

One practicable remedy, and only one, presents itself-the gradual education of readers through the very reading which now interests and satisfies them. In the genuine act of reading, we have not only a starting-point, but a continuous method of education. For progress is the law of mental life. The human mind is a developing organism: under normal conditions it neither stands still nor retrogrades. Under such conditions, if the literature adapted to further its progress is at hand, it tends to seize upon this literature in preference to that which either fails to quicken or actually stultifies it.

This fact has been repeatedly observed, where the experiment has been tried with individual readers or with a small group of them, as in settle- 
ment classes and in schools. The gradual disappearance, from situations so conditioned, of the books which are either palpably insincere or notably crude, at least suggests the possibility of making use of a similar procedure as a means of destroying over a wider area the demand for a type of literature which, though now socially useful, could not serve a more highly developed society.

To bring into the field of an individual reader's attention at the psychological moment the book which will then yield him most increase of capacity, is not always given to the writer-critic; but the teacher-critic finds this a most important part of his office. So far as experiment has been made on the point, a right sequence of books seems to be of itself an incredibly powerful agent in developing the reading-capacity of an individual. And if, in addition to this, teachers stand ready to further the reading-process by every other really efficient means, stimulating it by revealing some of its rich possibilities, defining it by bringing to light its social function and values, their students' progress from stage to stage must be even more rapid and assured.

Such a conception of the critic's function does, as a matter of fact, underlie our modern teaching of literature in the schools. It is, however, in many cases so imperfectly grasped and applied, that books which students cannot honestly read are 
untimely forced upon them, thus sacrificing the development of reading-capacity to the mere form of "doing" such and such writers or works; while the imposition of critical formulæ, emanating from text-book or teacher, too often seems to render unnecessary the pupil's personal experience with the literature prescribed. An abiding sense of what the student's own criticism of literature means to him, however crude and unsatisfactory it may be to others, and of the teacher's primary obligation to further his vital contact with any literature that can carry him a step beyond his present capacity, would serve to redeem English teaching from formality and barrenness, while developing a generation of readers who are bound to demand books on a constantly rising level of intelligence and taste.

The critic as teacher virtually chooses those whom he will teach by the progress he himself has made. And the critic as writer (whose office is equally, though less avowedly, preceptorial) chooses his readers by the same means. Those whose capacity to experience literature is fuller or finer than his will not care to listen to what he has to say; while those whose capacity is far below his cannot grasp it. Only those approximately, but not quite, at his own level, can he serve.

Having taken a step or two in advance of these, he constantly labors to close the gap between them by drawing the reader up to him. And so soon as 
he has done so, he must move beyond their common position, or the reader can no longer advance through him, but must find another helper.

To each reader, then, his own critic, and this critic often for only a limited period in his development. For the function of the critic is no empty honor, but a genuine utility, serving the sole end of the reader's limitless progress.

The texms-writer and teacher by no means cover all possible phases of the foritic's sociat activity. This activity may be carried on in an English classroom or on a lecture-platform; its results may be published in a popular magazine or in a learned review; it may take the form of club-work at a social settlement or of a dramatic experiment such as Professor George P. Baker's "Workshop"; it may involve copying manuscripts in the British Museum or taking down, as Professor John A. Lomax has done, the songs of cowboys on the Texas plains; but in all these and in many other guises, it seeks always the same end, namely, to further the activity of literature an agent of progress. And it reaches this end always by -one means,-by applying to every concrete problem presented to it the principle that literature is not alone a creature but also a creator of the society it serves.

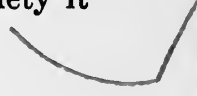


, 

call

Q Call BI L Hasten

for nom os thing

I went ti

(1) call Jo ln bey

(3) call jug

(4) call Mics

3) ad foo

(s) ald 



\section{PLEASE DO NOT REMOVE CARDS OR SLIPS FROM THIS POCKET}

\section{UNIVERSITY OF TORONTO LIBRARY}

PN

81

B84

1916

C. 1

ROBA 
